\title{
A COMPARATIVE STUDY ON STUDENTS' LEVEL OF ACCEPTANCE AND PREFERENCE OF CONVENTIONAL AND VIRTUAL MODE AT "GAUSUL AZAM MAIZBHANDERI MEDHA-BRITTHI (SCHOLARSHIP EXAM) PROGRAM IN FATIKCHARI, BANGLADESH
}

\author{
Md. Rabiul Hossen \\ Lecturer \\ Department of English \\ Nanupur Laila Kabir University College, Bangladesh \\ Associate Member \\ Darul Irfan Research Institute (DIRI), Bangladesh \\ E-mail: tasauf.darulirfan@gmail.com \\ Shahjada Syed Irfanul Hoque \\ Managing Trustee \\ Darul Irfan Research Institute (DIRI), Bangladesh \\ Nayeb Sajjadah Nasheen \\ Maizbhandar Darbar sharif, Fatikchari, Chittagong, Bangladesh \\ E-mail: tasauf.darulirfan@gmail.com \\ Prof. Dr Asif Mahbub Karim \\ FCGIA, Dean \\ Binary Post Graduate School \\ Binary University of Management and Entrepreneurship, Malaysia \\ E-mail: drasifmkarim@gmail.com \\ Dina Arjumand \\ Student \\ Department of "Urban \& Regional Planning" \\ Chittagong University of Engineering \& Technology \\ Associate Member \\ Darul Irfan Research Institute (DIRI), Bangladesh \\ E-mail: tasauf.darulirfan@gmail.com
}

\begin{abstract}
The students associated with the educational sector are facing a restructuring educational system for being pushed out of school by the elongated countrywide new-normal situation during COVID-19. In this pandemic situation, the virtual mode is welcome in the absence of a face-toface conventional mode of examination. So, participants' satisfaction, acceptance, and preference of exam mode need to be focused on. This paper addresses the determinants of
\end{abstract}


satisfaction, acceptance, and preference among the students of the Medha-Britthi examination. Data has been collected through a Telephone questionnaire survey from the participants of the school level of Bangladesh at the Maizbhanderi Medha-Britthi (scholarship) examination. The data has been analyzed using SPSS according to their responses on their satisfaction, acceptance \& preference of examination mode for the future. The result shows that according to their level of satisfaction, examinee communication, time \& cost-effectiveness, and ICT effectiveness, most of the students have preferred the online examination mode for the future. Few students have preferred conventional methods for a lack of digital devices, ICT efficacy, or lack of interest. This study also will take appropriate measures to overcome the barriers faced by the participants so that the preferable mode can be continued in the future.

Keywords: Level of Acceptance and Preference, Medha-Britti Scholarship Program, Conventional Mode, Virtual Mode, Digital Device.

\section{INTRODUCTION}

With an event like the COVID-19 crossing borders in an increasingly mobile world, the efforts in education may be challenged in other ways (Masuhay, 2020). The use of online learning attracted the attention of all educational contexts, particularly when the government of all countries closed schools and universities due to COVID-19 (Himat, 2021).In this situation, students have to depend on the online method to perform their examinations including non-formal examinations. As online exams become an important assessment method in online learning, it is essential to analyze learners' perceptions (Adanir et al., 2020)It is emergent to focus on the preference of participants on examination methods according to their level of satisfaction and interest. Students' interests and engagement are not the same in both physical and virtual modes of cocurricular activities such as exam participation. These depend on many socio-economic and demographic factors as well as efficacy and perceived usefulness. Online courses make possible new forms of working and learning together that would be difficult or impossible to use in the classroom-based course (Shen et al., 2004). The virtual method can ensure the participation of students from the whole country because students can perform the examination staying at home. Students who have a proper internet connection and required digital devices feel comfortable, interested, and attracted. Bangladesh is one of the low-mid income bracketed countries of the world where meeting up of basic needs for the mass people is still the major challenge. So it has been very challenging for some students in rural areas of Bangladesh as a developing country to get internet facilitates for their financial status.

They are facing a lack of electronic devices such as smartphones, laptops, and required an internet connection to perform the online examination. That's why they are lagging behind the examination which they used to perform regularly before the new-normal situation. But if the required internet facilities and the digital device can be ensured for those students, then it will be possible for those students to continue with the online process. The preferred exam mode should be continued in the future. Students' level of satisfaction and acceptance in the online examination and conventional examination can clear about the preference of the method. Based on their satisfaction and acceptance, one of the two methods should be chosen to be continued for the future.

The objectives of the paper are:

- To make a comparative study on the conventional and virtual process of examination according to participants' satisfaction and acceptance. 
- To analyze comparatively the preferable mode of exams of participants' interest, comfort, convenience.

- To take appropriate measures to overcome the barriers faced by the participants so that the preferable mode can be continued in the future.

This paper will be beneficial for finding out an examination mode for the future according to participants' level of satisfaction and acceptance. The study will help find out the barriers of participants while applying virtual mode. It will also be beneficial for taking measures to overcome the problems faced by participants and to continue with the virtual mode in the future.

\section{Problem Statement}

Gaushul Azam Maizbhandari Medha Britti (Non-formal Scholarship Exam) organized by "Maizbhandari Foundation" which is situated in Fatikchari, Chittagong, Bangladesh. Maizbhandari Foundation has successfully arranged its scholarship exam since 2013 through the conventional method by using written mode .In the conventional method, the number of participants was about one thousand where all of the participants used to attend paper mode exams which remark as the face-to-face way or physical way. This year, the world is facing a pandemic with a new normal situation. Corona Pandemic attacked Bangladesh on 08th March 2020 (Sarker, 2020). According to this situation, Maizbhandari Foundation also has taken a step for scholarship exams through virtual mode. So it developed a new model for its regular exam by using an electronic paper mode exam through a multiple choice question system.

\section{Research Questions}

- Which mode of examination is more satisfactory according to participants' comfort, easiness \& interest?

- Which mode is less-expensive and less-time consuming for the students?

- Can Virtual mode make the interest of using digital technology or encourage students to their study?

- Which mode is easier for the students to communicate with the examiner or follow their instructions?

- Which method is preferable for the future according to participants' opinions?

- Is there any positive correlation of the level of preference for the future with other variables?

\section{E-Examination}

\section{LITERATURE REVIEW}

Electronic Based Examination or E-Exam has become very useful, convenient, and popular by the proper implication of ICT (Information \& Communication Technology). As a form of assessment, evaluation, and feedback, online exams play an important role in online learning (Adanir et al., 2020). Online exams bring advantages such as test security, safe data storage, immediate exam results, cost-effectiveness, saving paper and time, and automated recordkeeping for learners, instructors, and institutions (Ilgaz \& Afacan Adanır, 2020)

\section{Level of Satisfaction and Preference of Examination Mode}

Learners' opinions are very important in the decision-making process before initiating online exams (Ilgaz \& Afacan Adanır, 2020). Evaluating the level of acceptance in online examination 
compared to conventional method is important in this new-normal situation during the era of ICT.

According to another paper, the survey From the study of Nardi and Ranieri (2019), most of the students have given positive feedback to the computer-based exam (E-exam) compared to the paper-based exam while only around $4 \%$ have a bad experience.In this study, it has been found that $76.34 \%$ of participants declared their preference for Computer Based Test (E-exam) in all final examinations, while $23.65 \%$ want to keep Paper Based Test.

According to the research of Candrlic, Katic, and Dlab (2014), 1231 paper-based and online tests were conducted to compare the preference of students in the paper-based exam and online exam. According to the comments of the students, most of them prefer the keyboard rather than a pencil so they would rather take online tests rather than paper-based tests.

From the study of Shen et al., (2004), about 58\% of participants recommend using the online exam for the future, $30 \%$ of students are neutral and the rest of them recommend the traditional one based on their level of perception, acceptance, and satisfaction.

\section{ICT Efficacy}

The impact of the Internet on education is an important issue that has caught educators' attention in recent years (Abubakar, 2019). The ICT provides a great development opportunity by contributing to information dissemination, providing an array of communication capabilities, increasing access to technology and knowledge among others (Darma et al., 2018).

\section{METHODOLOGY}

Participants: The participants are both male and female who are the regular students of our medha-britti scholarship program of school level who aged from 10 to 16.

Table 1. Participants according to Gender and Age

\begin{tabular}{|c|c|c|c|c|c|c|}
\hline \multirow{2}{*}{ Gender } & \multicolumn{4}{|c|}{ Age in year } & \multicolumn{2}{c|}{ Total participants } \\
\cline { 2 - 7 } & $10-11$ & $12-13$ & $14-15$ & $16-17$ & $\mathrm{~F}$ & $(\%)$ \\
\hline Male & 29 & 39 & 42 & 34 & 144 & $51.7 \%$ \\
\hline Female & 32 & 38 & 31 & 33 & 134 & $48.20 \%$ \\
\hline Total & 61 & 77 & 73 & 67 & 278 & $100 \%$ \\
\hline
\end{tabular}

Sampling Procedure: By using the "Sample size calculator", we have got the sample size for the paper is 278 based on our population size 1000 with the confidence level of $95 \%$.

Data Collection: Data has been collected from the regular participants who have experiences of both examination modes. A telephone questionnaire survey was conducted using 5 points Likert scale data as 5-strongly agree to 1-strongly disagree. The sample size was 278 as the population size is 1000 .

The Procedure of Data Analysis: Data has been analyzed using SPSS (Statistical Package for the Social Sciences) according to participant's responses about the statements in the questionnaire. Students' perception has been shown by using charts and relevant tables using Microsoft Excel 2019. And charts about correlation have made using SPSS. Cronbach alpha has done for checking the reliability among the statements in the questionnaire. Spearman rank 
correlation has been conducted for checking the correlation of students' preference for exam mode with other variables that are related to their experience while conducting the examination.

The scale of the Questionnaire: The questionnaire was designed by following a 5-point Likert scale to know the opinion about their perception of virtual mode compared to the conventional examination system.

\begin{tabular}{|c|c|c|c|c|}
\hline $\mathbf{1}$ & $\mathbf{2}$ & $\mathbf{3}$ & $\mathbf{4}$ & $\mathbf{5}$ \\
\hline $\begin{array}{c}\text { Strongly } \\
\text { disagree }\end{array}$ & Disagree & Neutral & Agree & Strongly agree \\
\hline
\end{tabular}

\section{Reliability Test}

\section{RESULTS}

Cronbach alpha method has been used for checking the reliability among the statements in the questionnaire which is a measure of internal consistency. The co-efficient value of Cronbach alpha has been found 0.91 which is considered very strong reliability among the statements in the questionnaire.

Participants' Perception of Examination Modes: For evaluating their opinion, the responses of the participants are analyzed by determining some variables like their level of satisfaction and acceptance, easiness of examinee communication, saving of time and money, and perceived usefulness of virtual examination compared to conventional examination.

Table 2. Percentage of participants' response about their perception of examination modes

\begin{tabular}{|c|c|c|c|c|c|}
\hline \multirow[t]{2}{*}{ Variables } & \multirow[t]{2}{*}{ Statement } & 5 & 3 & 2 & 1 \\
\hline & & Agree & Neutral & \multicolumn{2}{|c|}{ Disagree } \\
\hline \multirow{5}{*}{$\begin{array}{c}\text { Level of } \\
\text { satisfaction \& } \\
\text { acceptance }\end{array}$} & $\begin{array}{l}\text { The virtual model is more comfortable } \\
\text { than the conventional model. }\end{array}$ & $78 \%$ & $8.9 \%$ & \multicolumn{2}{|c|}{$12.94 \%$} \\
\hline & $\begin{array}{l}\text { The virtual model is easier than the } \\
\text { conventional for me. }\end{array}$ & $\begin{array}{c}77.33 \\
\%\end{array}$ & $9.72 \%$ & \multicolumn{2}{|c|}{$12.94 \%$} \\
\hline & $\begin{array}{l}\text { I was able to give full concentration more } \\
\text { easily in the virtual mode than the } \\
\text { conventional model. }\end{array}$ & $74.4 \%$ & $10.4 \%$ & \multicolumn{2}{|c|}{$15.1 \%$} \\
\hline & $\begin{array}{l}\text { I felt more interested in the virtual model } \\
\text { rather than the conventional model. }\end{array}$ & $76.2 \%$ & $8.9 \%$ & \multicolumn{2}{|c|}{$14.7 \%$} \\
\hline & $\begin{array}{l}\text { The virtual mode seems less-tiring } \\
\text { compared to the conventional model to } \\
\text { me. }\end{array}$ & $78.7 \%$ & $8.9 \%$ & \multicolumn{2}{|c|}{$12.23 \%$} \\
\hline \multirow{3}{*}{$\begin{array}{c}\text { Students' } \\
\text { communicatio } \\
\text { n with the } \\
\text { examinee }\end{array}$} & $\begin{array}{l}\text { Instructions of the examination were more } \\
\text { easy \& clear in virtual mode compared to } \\
\text { conventional mode. }\end{array}$ & $80.21 \%$ & $11.5 \%$ & \multicolumn{2}{|c|}{$8.27 \%$} \\
\hline & $\begin{array}{l}\text { Examiner was more helpful and co- } \\
\text { operative with me in the virtual mode } \\
\text { compared to the conventional model. }\end{array}$ & $80.21 \%$ & $11.5 \%$ & \multicolumn{2}{|c|}{$8.27 \%$} \\
\hline & Virtual mode is less expansive and saves & $88.12 \%$ & $8.9 \%$ & \multicolumn{2}{|c|}{$2.87 \%$} \\
\hline
\end{tabular}




\begin{tabular}{|c|c|c|c|c|}
\hline \multirow{2}{*}{$\begin{array}{l}\text { Time \& cost } \\
\text { effectiveness }\end{array}$} & \multicolumn{4}{|l|}{ travel costs. } \\
\hline & $\begin{array}{l}\text { Virtual mode is less time consuming } \\
\text { compared to conventional mode }\end{array}$ & $89.92 \%$ & $3.59 \%$ & $6.47 \%$ \\
\hline \multirow{2}{*}{$\begin{array}{l}\text { Perceived } \\
\text { usefulness }\end{array}$} & $\begin{array}{l}\text { Virtual mode encourages you to use } \\
\text { ICT/Digital Technology for your study. }\end{array}$ & $78 \%$ & $8.27 \%$ & $13.67 \%$ \\
\hline & $\begin{array}{l}\text { The virtual model has increased the } \\
\text { eagerness for regular examination. }\end{array}$ & $79.8 \%$ & $12.2 \%$ & $7.91 \%$ \\
\hline
\end{tabular}

Table 1 shows that the highest number of students is highly satisfied with the online examination and for having more comfort, easiness, interest in online examination compared to the conventional method. According to the response of the students, they have found a better communication and helpful response from the examinee in the online examination compared to conventional examination. In the same way, the examinee can provide sufficient information easily to the students in the virtual examination method. Most of the students as mentioned before think that online examination is less-expensive \& less-time consuming. Because they can consume travel time and money by conducting the examination staying at home with relax mode. According to their opinion, the virtual model of examination can encourage them to use the ICT/ digital technology which is very important for the new era of technology.

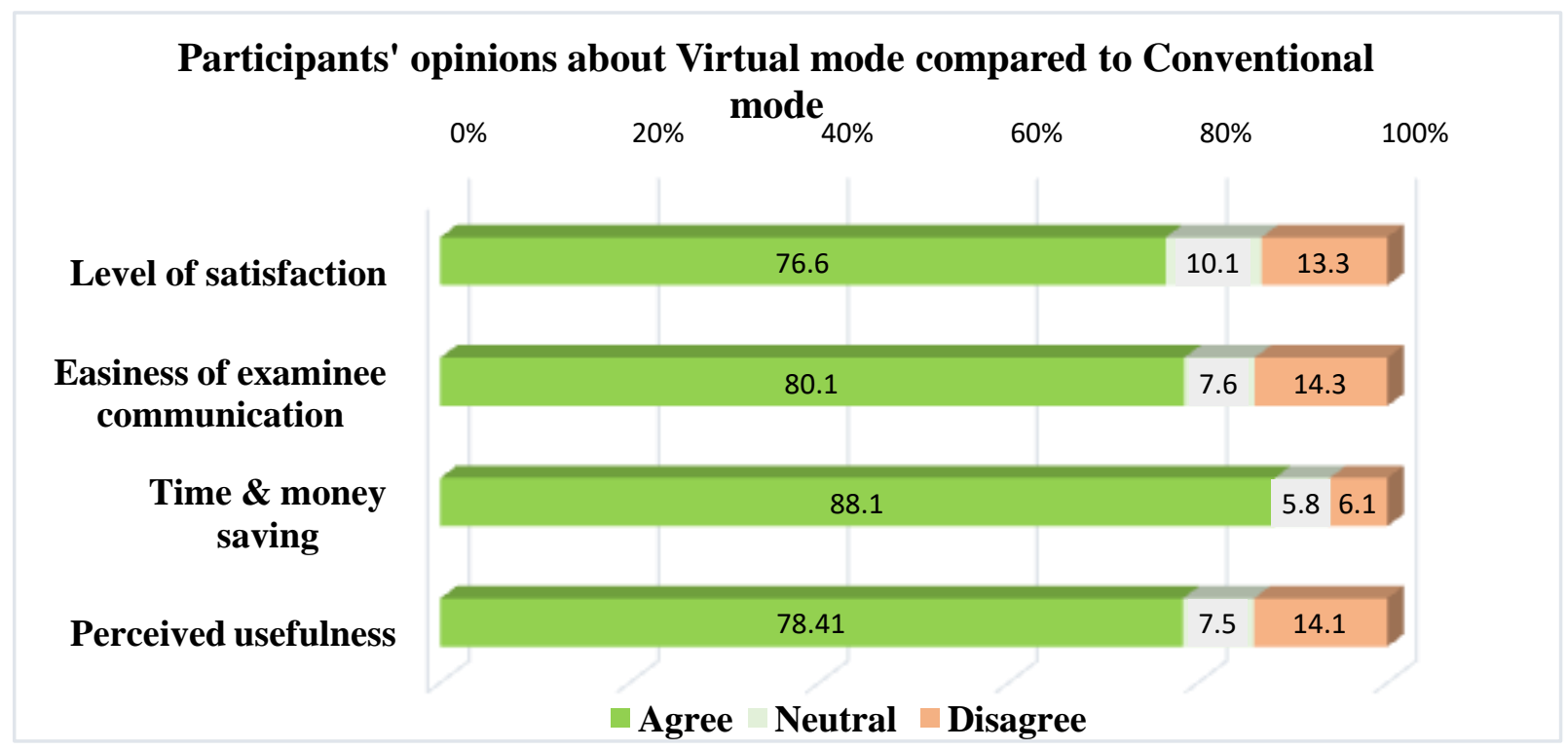

Figure1. Participants' overall opinion about virtual mode compared to conventional exam mode

This figure is presenting the mean of variables on overall responses about virtual mode compared to conventional mode. About $76.6 \%$ of the participants are more satisfied in virtual mode, $80.1 \%$ students think that they can make better communication while conduction online examination, $88.1 \%$ students can easily save their travel cost and time conduction online examination instead of conventional examination mode and $78.41 \%$ students get perceived usefulness in the online examination. 


\section{Level of Preference according To Participant's Responses}

Level of preference means the overall opinion of the participants about the choice of examination mode for the future. According to the level of satisfaction, acceptance, examinee communication, time \& cost-saving, and ICT effectiveness, the students can prefer the examination mode for future examination.

Table 3. Level of preference of examination mode for the future

\begin{tabular}{|c|c|c|c|c|c|c|}
\hline \multirow[t]{2}{*}{ Variable } & \multirow[t]{2}{*}{ Statement } & \multicolumn{4}{|c|}{ Responses } & \multirow{2}{*}{$\begin{array}{c}\text { Preference } \\
\text { of Exam } \\
\text { mode }\end{array}$} \\
\hline & & \multicolumn{2}{|c|}{ Scale } & $\mathbf{F}$ & $(\%)$ & \\
\hline \multirow{5}{*}{$\begin{array}{l}\text { Level of } \\
\text { preference }\end{array}$} & \multirow{5}{*}{$\begin{array}{l}\text { I prefer virtual } \\
\text { mode compared to } \\
\text { conventional mode }\end{array}$} & 5 & \multirow[t]{2}{*}{ Agree } & \multirow[t]{2}{*}{215} & \multirow[t]{2}{*}{77.34} & \multirow[t]{2}{*}{ Virtual mode } \\
\hline & & 4 & & & & \\
\hline & & 3 & Neutral & 24 & 8.64 & Neutral \\
\hline & & 2 & \multirow[t]{2}{*}{ Disagree } & \multirow[t]{2}{*}{39} & \multirow[t]{2}{*}{14.02} & \multirow{2}{*}{$\begin{array}{l}\text { Conventional } \\
\text { mode }\end{array}$} \\
\hline & & 1 & & & & \\
\hline
\end{tabular}

In light of the opinion of the students, it has been found that about $77 \%$ of the students prefer Virtual mode, $14 \%$ conventional mode $\& 9 \%$ students said that they can prefer any of the two methods. So most of the students prefer online examinations for the future.

\section{Spearman Rank Correlation}

Spearman rank correlation has been done for justifying the co-relation of the level of preference with participants' level of satisfaction, easiness of examinee communication, time and moneysaving and perceived usefulness.

Table 4. correlation between exam mode preference with the satisfaction level

\begin{tabular}{|c|c|c|c|}
\hline \multicolumn{2}{|c|}{ Spearman's rho correlation } & $\begin{array}{c}\text { Preference of } \\
\text { exam mode }\end{array}$ & $\begin{array}{c}\text { Level of satisfaction\& } \\
\text { acceptance }\end{array}$ \\
\hline $\begin{array}{c}\text { Preference of exam } \\
\text { mode }\end{array}$ & Correlation coefficient & 1 & $.770^{* *}$ \\
\cline { 2 - 4 } & Sig. (2-tailed) &. & 0 \\
\cline { 2 - 4 } & $\mathrm{N}$ & 278 & 278 \\
\hline \multirow{2}{*}{$\begin{array}{c}\text { Level of satisfaction } \\
\text { \& acceptance }\end{array}$} & Correlation coefficient & $.770^{* *}$ & 1 \\
\cline { 2 - 4 } & Sig. (2-tailed) & 0 &. \\
\cline { 2 - 4 } & $\mathrm{N}$ & 278 & 278 \\
\hline
\end{tabular}

From table 4, the preference of exam mode is strongly and positively correlated with the level of satisfaction and acceptance and the value of $\mathrm{r}$ is 0.770 .

Table 5. correlation between exam mode preference with easiness of communication

\begin{tabular}{|c|c|c|c|}
\hline \multicolumn{2}{|c|}{ Spearman's rho correlation } & $\begin{array}{c}\text { Preference of } \\
\text { exam mode }\end{array}$ & $\begin{array}{c}\text { Easiness of } \\
\text { communication with } \\
\text { examinee }\end{array}$ \\
\hline Preference of exam & Correlation coefficient & 1 & $.805^{* *}$ \\
\hline
\end{tabular}




\begin{tabular}{|c|c|c|c|}
\hline \multirow{2}{*}{ mode } & Sig. (2-tailed) & $\cdot$ & 0 \\
\cline { 2 - 4 } & $\mathrm{N}$ & 278 & 278 \\
\hline \multirow{2}{*}{$\begin{array}{c}\text { Easiness of } \\
\text { communication } \\
\text { with examinee }\end{array}$} & Correlation coefficient & $.805^{* *}$ & 1 \\
\cline { 2 - 4 } & Sig. (2-tailed) & 0 & $\cdot$ \\
\cline { 2 - 4 } & $\mathrm{N}$ & 278 & 278 \\
\hline
\end{tabular}

From table 5, the preference of exam mode is strongly and positively correlated with the Easiness of examinee communication and the value of $r$ is 0.805 .

Table 6. Correlation between exam mode preferences with Time \& Cost saving

\begin{tabular}{|c|c|c|c|}
\hline \multicolumn{2}{|c|}{ Spearman's rho correlation } & $\begin{array}{c}\text { Preference of } \\
\text { exam mode }\end{array}$ & $\begin{array}{c}\text { Time \& Cost } \\
\text { saving }\end{array}$ \\
\hline $\begin{array}{c}\text { Preference of exam } \\
\text { mode }\end{array}$ & Correlation coefficient & 1 & $.839^{* *}$ \\
\cline { 2 - 4 } & Sig. (2-tailed) &. & 0 \\
\cline { 2 - 4 } & $\mathrm{N}$ & 278 & 278 \\
\hline \multirow{3}{*}{ Time \& Cost saving } & Correlation coefficient & $.839^{* *}$ & 1 \\
\cline { 2 - 4 } & Sig. (2-tailed) & 0 &. \\
\cline { 2 - 4 } & $\mathrm{N}$ & 278 & 278 \\
\hline
\end{tabular}

From table 6 , the preference of exam mode is strongly and positively correlated with the savings of time and money and the value of $r$ is 0.839 .

Table 7. Correlation between exam mode preference with perceived usefulness

\begin{tabular}{|c|c|c|c|}
\hline \multicolumn{2}{|c|}{ Spearman's rho correlation } & $\begin{array}{c}\text { Preference of } \\
\text { exam mode }\end{array}$ & $\begin{array}{l}\text { Perceived } \\
\text { usefulness }\end{array}$ \\
\hline $\begin{array}{c}\text { Preference of exam } \\
\text { mode }\end{array}$ & Correlation coefficient & 1 & $.786^{* *}$ \\
\cline { 2 - 4 } & Sig. (2-tailed) &. & 0 \\
\cline { 2 - 4 } & $\mathrm{N}$ & 278 & 278 \\
\hline \multirow{2}{*}{$\begin{array}{c}\text { Perceived } \\
\text { usefulness }\end{array}$} & Correlation coefficient & $.786^{* *}$ & 1 \\
\cline { 2 - 4 } & Sig. (2-tailed) & 0 &. \\
\cline { 2 - 4 } & $\mathrm{N}$ & 278 & 278 \\
\hline
\end{tabular}

From table 7, the correlation between exam mode preference and perceived usefulness is strongly positively correlated and the value of $r$ is 0.786 .

\section{DISCUSSION}

Last, of all, we can say, according to participants' level of satisfaction and acceptance, easiness of communication of participants "with the examiner, saving of time and money, and having perceived usefulness, most of the students have preferred virtual mode compared to the conventional mode for the future. From Spearman rank correlation, it has been found that the level of preference for the future exam has a strong and positive correlation with the variables. If the student can prefer virtual mode for the future, a decision can be taken for arranging the examination in e-platform in the future. 
Bangladesh is one of the low-mid income bracketed countries of the world where meeting up of basic needs for the mass people is still the major challenge.

Less number of participants doesn't prefer online exams for having a lack of ICT efficacy or financial problems. Following measures should be taken for them so that the most preferable mode can be continued for the future.

- The Students Who Have Poor ICT Knowledge Should Be Trained By Providing Soft Material Like A Tutorial, Online Training For Making Them Able To Conduct Virtual Examination System.

- And Those Who Have Financial Problems Should Be Provided Some Soft Loan To Buy The Digital Device.

- Awareness About Digital Technology And E-Platform Examination Should Be Increased Among The Students And Their Parents Also.

Then all the students will be able to conduct the online examination perfectly and conveniently. Because in the new-norm situation, e-platform is the best and only way to conduct the regular examination perfectly.

While conducting the research work, some limitations have been found in the survey. Though it was a telephone questionnaire survey, some students of the whole population didn't pick up the phone; some has cut the call which was a waste of time \& energy. That's why we had called the participants which were more than our sample size for getting responses according to our exact sample size.

\section{REFERENCES}

Abubakar, M. T. (2019). Assessment of College Students' Preference on the Usage of Google Drive as a Learning Platform: An Empirical Evidence. American International Journal of Social Science Research, 4(2), 24-34. https://doi.org/10.46281/aijssr.v4i2.331

Adanir, G. A., Ismailova, R., Omuraliev, A., \& Muhametjanova, G. (2020). Learners' perceptions of online exams: A comparative study in Turkey and Kyrgyzstan. International Review of Research in Open and Distance Learning, 21(3), 1-17. https://doi.org/10.19173/irrodl.v21i3.4679

Candrlic, S., Katic, M. A., \& Dlab, M. H. (2014). Online vs. Paper-based testing: A comparison of test results. 2014 37th International Convention on Information and Communication Technology, Electronics and Microelectronics, MIPRO 2014 - Proceedings, July, 657-662. https://doi.org/10.1109/MIPRO.2014.6859649

Darma, S. A., Aliyu, F., \& Kurfi, S. A. (2018). The Role of Social Media in Empowering the Involvement of Women in Information Technology: A Case Study of Al-Qalam and Umaru Musa Yar'adua Universities. American International Journal of Social Science Research, 2(1), 7-27. https://doi.org/10.46281/aijssr.v2i1.164

Himat, A. N., Takal, M. H., \& Hakimi, M. F. (2021). AFGHAN STUDENTS' SATISFACTION FROM ONLINE LEARNING DURING COVID-19 AT KANDAHAR UNIVERSITY, KANDAHAR, AFGHANISTAN. American International Journal of Social Science Research, 6(1), 16-29. https://doi.org/10.46281/aijssr.v6i1.931 
Ilgaz, H., \& Afacan Adanır, G. (2020). Providing online exams for online learners: Does it really matter for them? Education and Information Technologies, 25(2), 1255-1269. https://doi.org/10.1007/s10639-019-10020-6

Masuhay, E. P. (2020). Adversaries on Covid-19 Set Forth an Argument Onward To Educational Endeavor: Resulting To Develop a Modular Concept in the Learning Process. American International Journal of Social Science Research, 5(2), 26-37. https://doi.org/10.46281/aijssr.v5i2.520

Nardi, A., \& Ranieri, M. (2019). Comparing paper-based and electronic multiple-choice examinations with personal devices: Impact on students' performance, self-efficacy and satisfaction. British Journal of Educational Technology, 50(3), 1495-1506. https://doi.org/10.1111/bjet.12644

Sarker, A.-A. (2020). People in Northern Bangladesh: Corona Pandemic 2020 Aftermath Action. American International Journal of Social Science Research,5(2), 38-40. https://doi.org/10.46281/aijssr.v5i2.581

Shen, J., Cheng, K., Bieber, M., \& Hiltz, S. R. (2004). Traditional In-class Examination vs . Collaborative Online Examination in Asynchronous Learning Networks : Field Evaluation Results. Proceedings of the Tenth Americas Conference on Information Systems,August, 111. Retrieved from http://web.njit.edu/ bieber/pub/ShenAMCIS04_final.pdf

\section{Appendix A: Questionnaire of Telephone Survey \\ APPENDICES}

Authors have designed a questionnaire for telephone using five variables named Level of satisfaction and acceptance, students' communication with the examiner, time and costeffectiveness, perceived usefulness, and level of preference of exam mode. Under each variable, they asked the following statements. The questionnaire followed 5 points Likert scale from strongly agreed to strongly disagree with the statements.

\begin{tabular}{|c|c|c|c|c|c|c|}
\hline \multirow[t]{2}{*}{ Variables } & \multirow[t]{2}{*}{ Statements } & \multicolumn{5}{|c|}{$\begin{array}{l}\text { Responses of } \\
\text { participants }\end{array}$} \\
\hline & & 1 & 2 & 3 & 4 & 5 \\
\hline \multirow{5}{*}{$\begin{array}{c}\text { Level of } \\
\text { satisfaction \& } \\
\text { acceptance }\end{array}$} & $\begin{array}{l}\text { The virtual model is more comfortable than the } \\
\text { conventional model. }\end{array}$ & & & & & \\
\hline & $\begin{array}{l}\text { The virtual model is easier than the conventional } \\
\text { for me. }\end{array}$ & & & & & \\
\hline & $\begin{array}{l}\text { I was able to give full concentration more easily } \\
\text { in the virtual mode than the conventional model. }\end{array}$ & & & & & \\
\hline & $\begin{array}{l}\text { I felt more interested in the virtual model rather } \\
\text { than the conventional model. }\end{array}$ & & & & & \\
\hline & $\begin{array}{l}\text { The virtual mode seems less-tiring compared to } \\
\text { the conventional model to me. }\end{array}$ & & & & & \\
\hline
\end{tabular}




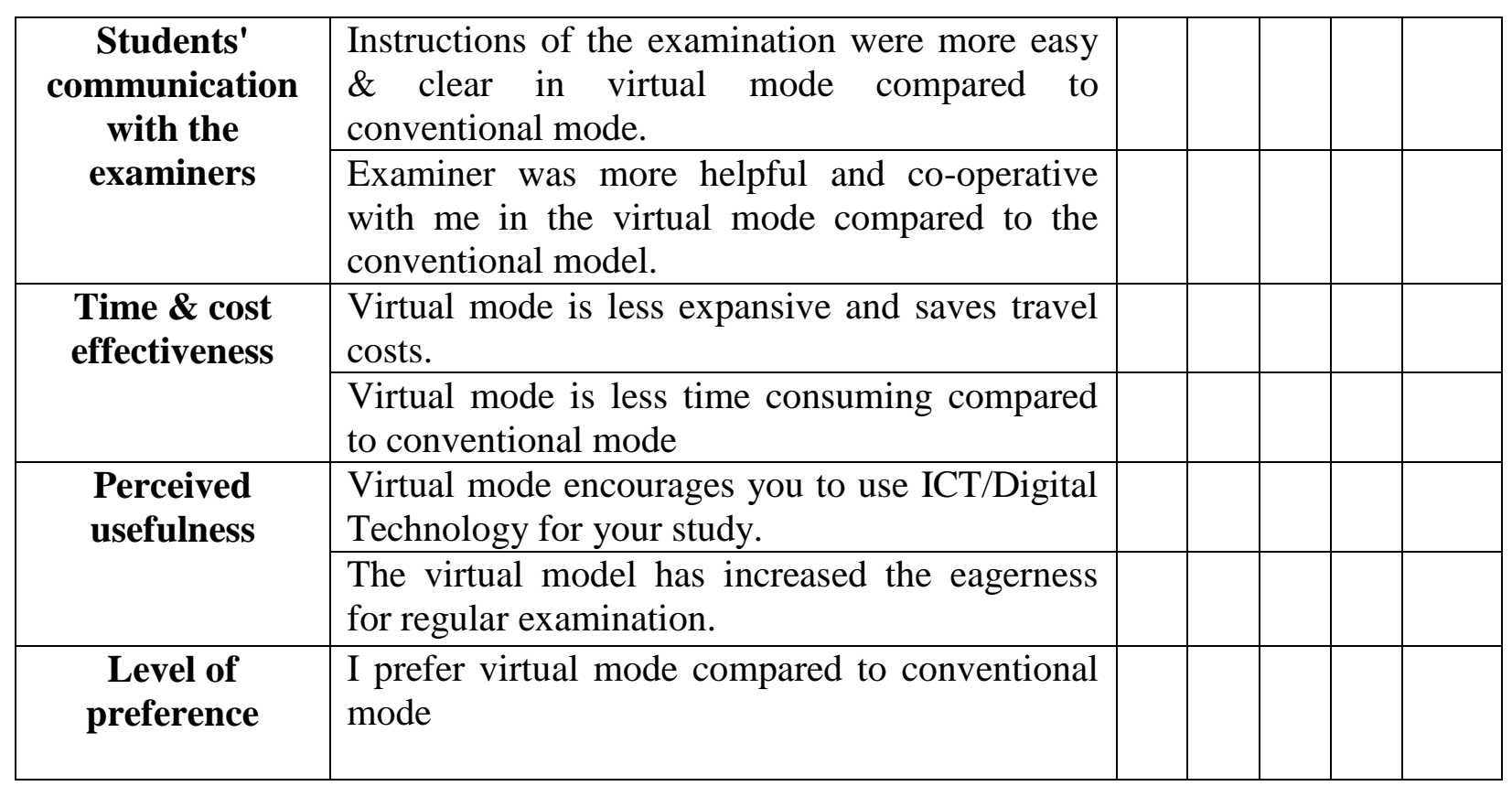

\section{Copyrights}

Copyright for this article is retained by the author(s), with first publication rights granted to the journal. This is an open-access article distributed under the terms and conditions of the Creative Commons Attribution license (http://creativecommons.org/licenses/by/4.0/) 